\title{
Miss Scarlett, in the laboratory, with the microscope
}

$\mathrm{T}$ here is a small newspaper clipping, engulfed by a slew of other notices and warnings, which stays quietly pinned to a corkboard in our lunchroom in the Stem Cell and Cancer Research Institute here at McMaster University in Hamilton, Ontario.

It was a rebuttal written by a local resident with regards to our research on cancer stem cells. It stated "unless this major breakthrough is the result of adult and not embryonic stem cell research, then Institute's ethics are suspect."

The first time I read this article I laughed in sheer naivety and denial.

My ethics are not suspect, nor are my intentions or beliefs. I plan to do great things with my training as an $\mathrm{MD} / \mathrm{PhD}$ student, great things to cure cancer and save the world and all of those other things clinicians voice to their patients or researchers write in their grants.

My unadulterated love for research is pure, stem cells are clean beautiful microcosms to observe and if I work hard enough I will be rewarded and save patient lives.

These were all myths, floating memes that bathed me in a warm broth of disillusion until I reread the 1-inch paper clipping another time.

I realized that no matter how much you do, nothing is embraced without public understanding, no matter what

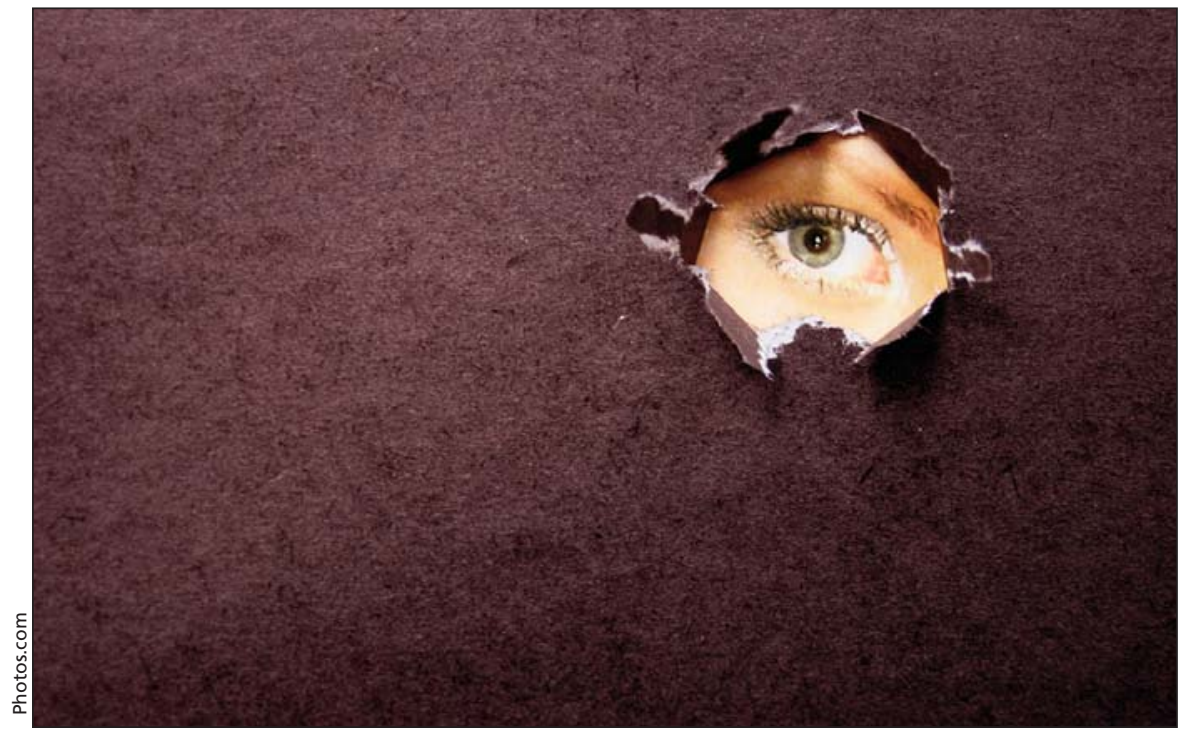

the controversial topic, nothing is relayed without patience, and no matter how hard you work, nothing comes easy.

In medical research, every step is a fight; first battling your own self-doubt, then that of your peers; required and trained to challenge every step of your methodology and finally facing the world, embodied in a paper clipping, which may never fully embrace what you do or agree, but is the reason you can and will continue on.

Now, as I eat lunch everyday, I stare at the clipping contemplating how much impact it has had on how I perceive myself as a future clinician scientist and how much of a suspect (and not a hero) I am considered in this game of "Clue" we call medical research. - Chelsea Maedler-Kron, Hamilton, Ont.

DOI:10.1503/cmaj.091218

CMAJ invites contributions to "Dispatches from the medical front," in which physicians and other health care providers offer eyewitness glimpses of medical frontiers, whether defined by location or intervention. Submissions, which must run a maximum 700 words, should be forwarded to: wayne.kondro @cmaj.ca. 